GRASAS Y ACEITES 70 (4)

October-December 2019, e326

ISSN-L: 0017-3495

https://doi.org/10.3989/gya.1044182

\title{
Effects of microwave and conventional heating on the oxidative stability of corn oil enriched with different antioxidants
}

\author{
A. Baştürk ${ }^{\bowtie}$ \\ Department of Food Engineering, Faculty of Engineering, Van Yüzüncü Y1l University, Van 65080, Turkey. \\ ${ }^{\circledR}$ Corresponding author: ayhanbasturk@gmail.com
}

Submitted: 04 October 2018; Accepted: 18 December 2018; Published online: 17 July 2019

\begin{abstract}
SUMMARY: Four different corn oil samples including stripped ( $\mathrm{SCO}$, Control), refined (RCO), stripped corn oil enriched with rosemary extract (SCO+ROS) and ascorbyl palmitate (SCO+AP) were exposed to microwave $(\mathrm{MWH})$ and conventional heating $(\mathrm{CVH})$. For both heating methods, peroxide value $(\mathrm{PV})$ and conjugated dienes increased at up to $230{ }^{\circ} \mathrm{C}$, at which temperature hexanal (HEX) and conjugated trienes started to increase instead. Kinetic analysis revealed that PV and HEX formation were first ordered and the reaction rate among the samples was as follows: Control $>\mathrm{SCO}+\mathrm{ROS}>\mathrm{RCO}>\mathrm{SCO}+\mathrm{AP}$ for $\mathrm{PV}$ and $\mathrm{SCO}+\mathrm{ROS}>\mathrm{RCO}>$ $\mathrm{SCO}+\mathrm{AP}>\mathrm{Control}$ for HEX. The unsaturated fatty acid contents of $\mathrm{CVH}$ and MWH treated samples showed 9.5 and $12.9 \%$ reduction in SCO, while they were 2.9 and $7.7 \%$ in RCO, 3.6 and $6.1 \%$ in SCO+ROS, and finally 4.0 and $4.8 \%$ in SCO+AP. It was concluded that MWH led to a more severe deterioration and that the antioxidant activity of ROS was superior to that of AP for both heating methods.
\end{abstract}

KEYWORDS: Ascorbyl Palmitate; Corn Oil; Hexanal; Kinetics; Microwave; Oxidation

RESUMEN: Efectos del calentamiento mediante horno microondas y convencional sobre la estabilidad oxidativa del aceite de maíz enriquecido con diferentes antioxidantes. Cuatro muestras diferentes de aceites de maíz que incluyen aceites de maíz crudo (SCO, Control), refinados (RCO) y crudo enriquecido con extracto de romero $(\mathrm{SCO}+\mathrm{ROS})$ y palmitato de ascorbilo $(\mathrm{SCO}+\mathrm{AP})$ se expusieron a microondas $(\mathrm{MWH})$ y calentamiento convencional $(\mathrm{CVH})$. Para ambos métodos de calentamiento, el índice de peróxido (PV) y los dienos conjugados aumentaron hasta $230{ }^{\circ} \mathrm{C}$, a partir de donde hexanal (HEX) y trienos conjugados comenzaron a aumentar. El análisis cinético reveló que la formación de PV y HEX es de primer orden y la velocidad de reacción entre las muestras fue la siguiente: Control $>\mathrm{SCO}+\mathrm{ROS}>\mathrm{RCO}>\mathrm{SCO}+\mathrm{AP}$ para $\mathrm{PV}$ y $\mathrm{SCO}+\mathrm{ROS}>\mathrm{RCO}>$ $\mathrm{SCO}+\mathrm{AP}>\mathrm{Control}$ para HEX. El contenido de ácidos grasos insaturados de las muestras tratadas con $\mathrm{CVH}$ y MWH mostró una reducción de 9,5 y 12,9\% en SCO, mientras que fueron de 2,9 y 7,7\% en RCO, 3,6 y 6,1\% en SCO+ROS, y finalmente 4,0 y 4,8\% en SCO+AP, respectivamente. Se concluye que el MWH condujo a un deterioro más severo y la actividad antioxidante de ROS fue superior en comparación con la de AP para ambos métodos de calentamiento.

PALABRAS CLAVE: Aceite de maiz; Cinética; Hexanal; Microonda; Oxidación palmitato de ascorbilo

ORCID ID: Baştürk A https://orcid.org/0000-0001-7701-9306

Citation/Cómo citar este artículo: Baştürk A. 2019. Effects of microwave and conventional heating on the oxidative stability of corn oil enriched with different antioxidants. Grasas y Aceites 70 (4), e326. https://doi.org/10.3989/gya.1044182

Copyright: C2019 CSIC. This is an open-access article distributed under the terms of the Creative Commons Attribution 4.0 International (CC BY 4.0) License. 


\section{INTRODUCTION}

Microwave heating has been used for many years in the food industry. It has been a useful tool for improving the success of several unit operations, including extraction and filtration (Tan et al., 2001). In such operations, microwave heating has been advantageous over conventional heating due to reduced process time and improved food quality. On the other hand, the oxidative stability of some fats and oils has been reported to be negatively affected by microwave heating (Tan et al., 2001). Albi et al., (1997) reported a greater loss in oxidative quality in various oils and fats. Yoshida et al., (1992b) also reported that the microwave heating of vegetable oils and fatty foods led to a loss in some vitamins, the isomerization of fatty acids and thermo oxidative degradation. All these show that microwave heating has some detrimental effects on the quality and composition of oils and fatty foods.

Autoxidation is the main reaction in the degradation of food lipids, and heating plays an important role in both industrial and home processing. It also entails economic, nutritional, taste and flavor safety and preservation aspects for oily foodstuff. Oils with high contents in unsaturated, mainly polyunsaturated fatty acids are more susceptible to oxidation (Shahidi and Wanasundara, 1996).

Lipid oxidation first results in hydroperoxide formation, which then degrades into hydrocarbons, aldehydes, and ketones in the later stages of oxidation. The latter compounds tend to be volatile and are responsible for the rancid flavor formed during oxidation in fatty foods. Therefore, lipid oxidation is examined in two stages, the first of which is primary and the second of which is secondary oxidation. Degradation indices assess these primary and secondary oxidation products and are used as measures of lipid quality and oxidative stability (Frankel, 2010).

Primary oxidation of oils and fats is generally evaluated by parameters including peroxide value (PV), conjugated dienes (K232) and trienes (K270) as indicators of initial oxidation. The anisidine value $(\mathrm{AV})$ and thiobarbituric acid reactive substances (TBARS) are usually the parameters used as markers of secondary oxidation. Recently, hexanal (HEX) has been a popular index to show the phase of oxidation. HEX is known to be produced by the oxidation of linoleic acid (Shahidi, 1998).

Antioxidants are known to be effective in inhibiting lipid oxidation and generally classified as natural and synthetic antioxidants depending on the source or the method used for their production. Natural antioxidants are preferred over synthetic antioxidants, as they are perceived to be safer by consumers. In fact, the use of some of synthetic antioxidants is limited in foods due to their potential toxicity and carcinogenicity (Chung et al., 2012). One of the most commonly known natural antioxidants with radical scavenging activity is tocopherols (TOC) (Shahidi and Zhong, 2005). Another widely used natural antioxidant is ascorbic acid. However, its solubility is very limited in oils due to its hydrophilic nature. Thus, ascorbyl palmitate, which is a lipophilic ester of ascorbic acid, is used in edible oils as antioxidant (Benedini et al., 2011). In addition, herbal extracts are considered as natural antioxidant sources due to their potential for stabilizing edible oils. Among them, rosemary (Rosmarinus officinalis L.) extract (ROS) is known for its high antioxidant activity (Chen et al., 2014). In the relevant literature, there are many studies concerning the high antioxidant activity of ROS. However, there is limited information related to the oxidative stability of microwave and conventional-heated corn oil in the presence of different antioxidants.

The kinetics of lipid oxidation were previously studied in detail by Labuza (1971) and Karel (1992). According to Labuza (1971), oxidation was generally half-order in vegetable oils and in the case of antioxidant addition, this may be converted into first-order and sometimes zero-order in complex food systems. There are several studies on the kinetics of lipid oxidation with the use of various antioxidants. Most of these studies report on the kinetics of lipid oxidation based on PV and K232, while in the present study, oxidation kinetics were studied based on PV and HEX, the first of which is for primary and the latter for secondary oxidation products. In addition, the oxidation kinetics were mostly based on a specific triglyceride or fatty acid in these studies. There is a limited number of kinetic studies on the oxidation of real lipid systems such as vegetable oil, as they are or in the presence of antioxidants. In the present study, the oxidation kinetics of corn oil were studied, for the first time, based on both primary and secondary oxidation products in the presence of different antioxidants, as microwave heating is heavily used for foods formulated with vegetable oils like corn oil.

Here, in this study, the effects of microwave heating $(\mathrm{MWH})$ and conventional heating $(\mathrm{CVH})$ on the oxidative stability of corn oil were investigated in the presence of added antioxidants, AP and ROS, in comparison with $\mathrm{SCO}$ and RCO with its natural TOC content. In addition, the oxidation kinetics of corn oil were comparatively studied based on PV and HEX during microwave heating to examine the effects of antioxidants on oxidation kinetics.

\section{MATERIALS AND METHODS}

\subsection{Materials}

RCO (Orkide, Tekirdağ, Turkey) was obtained in a $5 \mathrm{~L}$ container from a local grocery store in Van, Turkey and stored in ambient 
conditions until samples were prepared. Once sampled, all the samples were stored at $4{ }^{\circ} \mathrm{C}$ until analyses were performed, which were completed within 3 months. A mixture of 37 fatty acid methyl esters (FAME; C4-C24) and a $2 \mathrm{~cm}$ SPME fiber coated with $50 / 30 \mu \mathrm{m}$ divinylbenzene/carboxen/polydimethylsiloxane were purchased from Supelco Co (Bellefonte, PA, USA). Leaves of Rosmarinus officinalis L. were obtained from Deva Co. (Manisa, Turkey). AP, hexane, isopropyl alcohol, isooctane, 2-methyl3-heptanone and aluminium oxide were obtained from Sigma-Aldrich Co (St. Louis, MO, USA). All solvents and reagents from various suppliers were of the highest purity needed for each application.

\subsection{Corn oil stripping}

Stripping was performed according to Yoshida et al., (1992a) with slight modifications. First, natural antioxidants, namely the tocopherols in RCO, were removed according to the method suggested by Baştürk et al., (2018). Then, the natural tocopherol content was analyzed before and after the treatment as confirmed by high performance liquid chromatography (HPLC).

\subsection{Preparation of oil samples}

Only fresh rosemary leaves were used in the ethanol extraction. These leaves were washed under running tap water. Excessive water from the rosemary leaves was removed using a paper towel. The leaves were then frozen at $-18^{\circ} \mathrm{C}$ for $24 \mathrm{~h}$ and underwent a lyophilization process (LabconcoFreezone 4.5, Kansas City, MO, USA). The freeze-dried leaves were crushed using a porcelain mortar and pestle, and then stored in dark colored bottles in ambient conditions until the time of extraction. $20 \mathrm{~g}$ of dried rosemary leaves were used for solvent extraction using a Soxhelet apparatus and a mixture of ethanol:water (80:20) as solvent. Solvent extraction was carried out for $6 \mathrm{~h}$ and the resultant extractsolvent mixture was processed by a rotary evaporator (Heidolph, Schwabach, Germany) at $65 \mathrm{rpm}$ and $40{ }^{\circ} \mathrm{C}$ to collect the solvent. The extract (ROS) obtained was freeze-dried and kept in dark colored bottles in ambient conditions until use.

Four of the samples studied were SCO (Control, separated from its natural antioxidants), RCO (as it is, with its natural antioxidant content, $890 \mathrm{ppm}$ TOC), SCO+AP (stripped corn oil with added AP at 200 ppm) and SCO+ROS (stripped corn oil with added ROS at $800 \mathrm{ppm}$ ). For preparation of $\mathrm{SCO}+\mathrm{AP}, 0.2 \mathrm{~g}$ of AP were first dissolved in $10 \mathrm{~mL}$ of acetone and this mixture was directly added to $1 \mathrm{~kg}$ of SCO to obtain $200 \mathrm{ppm}$ AP containing SCO+AP sample. Similarly, for the preparation of SCO+ROS, $0.8 \mathrm{~g}$ of ROS were first dissolved in $20 \mathrm{~mL}$ of ethanol and this mixture was directly added to $1 \mathrm{~kg}$ of SCO to obtain $800 \mathrm{ppm}$ ROS containing SCO+ROS sample.

\subsection{Microwave and conventional heating}

A microwave oven (Bosch, Model FD909, Stuttgart, Germany) and an electric oven (Arçelik, $9440 \mathrm{H}$ Elektroturbo, İstanbul, Turkey) were used in this study. $20 \mathrm{~g}$ of each sample were prepared in $50 \mathrm{~mL}$ pyrex tubes. For each time point, two tubes of each sample were heat-treated, one for chemical analyses (FAME, PV, K232 and K270) and the other for the HEX analysis. All analyses were performed in 3 replicates. For MWH treatment, samples were simultaneously heated in the center of the rotating plate. The samples were microwaved separately for $2,4,6,8,10,12,16,20,24$ and 30 $\mathrm{min}$, and the temperature of the samples was immediately measured by a thermocouple (Testo $175 \mathrm{~T} 3$ datalogger, Termokupl, Istanbul, Turkey) right after heating once the set time was completed. For $\mathrm{CVH}$ treatment, each sample was heated for a particular time to raise the samples to identical temperatures obtained in MWH for the corresponding sample.

During MWH treatment, the temperatures of the samples were recorded for each time point and these samples were coded from I to XI. Making a fair comparison among these two different heating treatments was only possible if the combination of time and temperature points in each heating treatment were comparable. For this purpose, the temperature reached for each sampling time in $\mathrm{MWH}$ was taken into account and paired with its relevant counterpart in the $\mathrm{CVH}$ treatment.

All 4 samples were heated in a $\mathrm{CVH}$ oven to the level of temperatures reached in MWH for their counterpart samples. As an example, the $2^{\text {nd }}$ sample of CVH was heated until the sample temperature reached to $93{ }^{\circ} \mathrm{C}$, which was the temperature of the sample treated with MWH for 2 minutes. Similarly, the last sample was heated until its temperature reached $284^{\circ} \mathrm{C}(\mathrm{XI})$, which was the highest temperature reached in MWH. Thus, 11 samples were heated in $\mathrm{CVH}$ as counterpart of each sample treated in MWH for different periods of time. Then, the samples were cooled and kept at $-18^{\circ} \mathrm{C}$ until the analyses. 2 independent series of experiments were carried out and the analyses were performed in triplicate unless otherwise stated.

\subsection{Analytical procedures}

Oxidation measurements. Peroxide value (PV), conjugated diene (K232), and conjugated triene (K270) were determined according to the procedures of the AOCS Official Method Cd 8-53 and Ch 5-91, respectively (AOCS, 1989), using a 
UV-VIS spectrophotometer (Agilent 8453, Agilent Technologies, Santa Clara CA, USA) for K232 and K270 readings.

Hexanal analysis. The hexanal (HEX) content was determined by Solid Phase Micro Extraction (SMPE) according to the method proposed by Javidipour and Qian (2008) with slight modifications. A 2 cm SPME fiber was used for the extraction of HEX. The SPME fiber was conditioned in a gas chromatograph injection port at $270{ }^{\circ} \mathrm{C}$ for $1 \mathrm{~h}$ before use. $10 \mathrm{~g}$ of each sample were divided into 2 of $5 \mathrm{~g}$ portions for the duplication of SPME analysis for each treatment. After sample preparation, $5 \mathrm{~min}$ of equilibration at $40{ }^{\circ} \mathrm{C}$ with constant stirring were applied before the SPME fiber was exposed for $30 \mathrm{~min}$ to the headspace of the vial for HEX extraction. After the extraction, desorption was performed in the injection port of an Agilent 6890 series GC (Agilent Technologies, Palo Alto, CA). The injector temperature was $250{ }^{\circ} \mathrm{C}$ and the splitless injection mode was used for $5 \mathrm{~min}$. The samples were analyzed on a HP-Innowax column (30 m, $0.25 \mathrm{~mm}$ i.d., $0.25 \mu \mathrm{m}$ film thickness, J\&W Scientific, Folsom, Ca, USA). Helium was used as carrier gas at a constant flow rate of $2 \mathrm{~mL} / \mathrm{min}$. The oven temperature was $35^{\circ} \mathrm{C}$ for $5 \mathrm{~min}$, and increased to $75^{\circ} \mathrm{C}$ at a rate of $8{ }^{\circ} \mathrm{C} / \mathrm{min}$, then increased to 220 ${ }^{\circ} \mathrm{C}$ at a rate of $40{ }^{\circ} \mathrm{C} / \mathrm{min}$ and held at this final temperature for $5 \mathrm{~min}$ while the FID detector temperature was $270{ }^{\circ} \mathrm{C}$. The concentration of HEX was calculated based on the calibration curve that was constructed by linear regression of the concentration ratio (concentration of compound/concentration of internal standard) and peak area ratio (area of compound/area of internal standard).

Determination of tocopherol content. $1 \mathrm{~g}$ of each oil in $9 \mathrm{~g}$ of hexane was injected into a normal phase high-performance liquid chromatography (HPLC) to analyze tocols (AOCS, 2003) using a Shimadzu SCL-10A HPLC system (Kyoto, Japan). The column used for separation was a Lichrosorb Si60-5

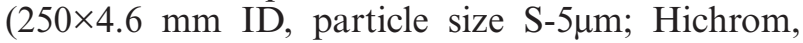
Reading, UK). The separation and quantification of tocopherols were based on the Official Method Ce 8-89 (AOCS, 2003).

Determination of fatty acid composition. The fatty acid composition of the oil samples was determined according to the procedure given in AOAC, (1990). The analysis of fatty acid methyl esters (FAMEs) was done on an Agilent 6890 series GC (Agilent Technologies, Palo Alto, CA) equipped with a FID. $30 \mathrm{~m}$ fused silica capillary column (id=0.25 $\mathrm{mm}$ ) coated with $0.25 \mathrm{~mm}$ of $\mathrm{CP}$ wax $52 \mathrm{CB}$ (Chromopack), chain length with respect to standard FAMEs (47885-U, Supelco). The FAMEs of the samples were quantified according to Supelco, (Bellefonte, PA) which was used as separation column. Helium was used as the carrier gas at a flow rate of $1.5 \mathrm{~mL} / \mathrm{min}$ and a split ratio of $1: 10$. The working temperatures of the injector, column and detector were 250,120 and $260^{\circ} \mathrm{C}$, respectively. The samples were injected into the column inlet using an Agilent 7683 B series automatic injector. FAMEs were identified by comparison of retention time and equivalent to their percentage area (AOAC, 1990).

\subsection{Statistical analysis}

Statistical analyses were performed using SPSS software (version 20.0 for Windows, SPSS Inc., Chicago, Illinois). The experimental data were expressed as mean \pm standard deviation of 3 repetitions and were analyzed using one-way ANOVA at a significance level of $p<0.05$. Differences among the means were compared using Tukey's HSD posthoc test.

\subsection{Data analysis}

A kinetic analysis was performed only for MWHtreated samples, as the heating times were evident. Oxidation is well known as being a series of complex reactions (Crapiste et al., 1999). The synergistic and antagonistic effects of several internal and external parameters lead to oxidation being a highly complex process, and therefore, no simple kinetic model alone can be applied to explain this process (Adhvaryu et al., 2000). In this study, the analyses of kinetic data were done according to the kinetic model suggested by Crapiste et al., (1999).

In this model, the orders of the reactions were not restricted and the kinetic expression of the autoxidation was written as Eq. (1):

$$
d P V / d t=k_{1} P V^{\alpha}-k_{2} P V^{\beta}
$$

where, $\mathrm{PV}$ is the peroxide value, $\mathrm{t}$ is time, $\mathrm{k}_{1}$ and $\mathrm{k}_{2}$ are the autocatalytic and decomposition rate constants, respectively, and $\alpha$ and $\beta$ are the orders of the oxidation and decomposition reactions, respectively. In addition, the increasing rate of hexanal (Hex), which represents the contents of secondary oxidation products, was used to solve Eq. 1, assuming that the decomposition rate of PV is equal to the production rate of Hex (Eq. 2):

$$
d H e x / d t=k_{2} P V^{\beta}
$$

The differential method was used to solve Eq. 2 and the numerical method was used to determine $\mathrm{dHex} / \mathrm{dt}$ values from raw data. The increase rate of Hex was determined using Hex values measured during storage. Eq. 2 was linearized and subsequently Eq. 3 was obtained:

$$
\ln (d \text { Hex } / d t)=\ln \left(k_{2}\right)+\beta \ln (\mathrm{PV})
$$


$\ln (d H e x / d t)$ versus $\ln (\mathrm{PV})$ was plotted for each sample, and slope and intercept of the line were determined as $\beta$ and $\ln \left(k_{2}\right)$, respectively. Thereafter, Eq. 1 was rewritten as Eq. 4;

$$
d P V / d t+k_{2} P V^{\beta}=k_{1} P V^{\alpha}
$$

and then linearized and Eq. 5 was obtained:

$$
\ln \left(d P V / d t+k_{2} \mathrm{PV}^{\beta}\right)=\ln \left(k_{1}\right)+\alpha \ln (P V)
$$

$\left(\ln \left(d P V / d t+k_{2} \mathrm{PV}^{\beta}\right)\right.$ versus $\ln (\mathrm{PV})$ was plotted for each sample, and the slope and intercept of the line were determined as $\alpha$ and $\ln \left(k_{1}\right)$, respectively.

\section{RESULTS AND DISCUSSION}

The refined corn oil as obtained from the marketplace was tested for its original antioxidant content by HPLC before the stripping process. It was found that the natural tocopherol (TOC) content of RCO was $890 \mathrm{ppm}$ in total (280 ppm $\alpha$-tocopherol, 236 ppm $\beta$-tocopherol, $353 \mathrm{ppm} \gamma$-tocopherol and 21 ppm $\delta$-tocopherol). It was also confirmed that SCO had no TOC left after the stripping process based on HPLC analysis.

\subsection{Fatty acid composition}

The fatty acid profile plays a key role in the deterioration of oils and is greatly affected during the deterioration process. Therefore, the fatty acid compositions of the MWH and CVH samples were determined at the beginning, in the middle and at the end of both heat treatments (Table 1). The most abundant fatty acid in corn oil was C18:2 (53.61\%) followed by C18:1 (31.43\%), C16:0 (10.63\%), C18:0 $(2.34 \%)$ and $\mathrm{C} 18: 3(0.25 \%)$. According to the results obtained, $\mathrm{MWH}$ and $\mathrm{CVH}$ treatments significantly reduced the C18:2 content in the samples as expected. The MWH treatment led to a higher decrease in the C18:2 content in the descending order of Control (SCO), $\mathrm{RCO}, \mathrm{SCO}+\mathrm{AP}$ and SCO+ROS. In the selected heating periods coded as I $\left(22^{\circ} \mathrm{C}\right)$, IV $\left(184^{\circ} \mathrm{C}\right)$ and $\mathrm{XI}\left(284^{\circ} \mathrm{C}\right)$; the total contents of SFA and PUFA significantly changed $(p<0.05)$. While SFA content increased at IV and XI time points, the PUFA content decreased and the MUFA content showed no significant change. Similar results were reported by Shahidi and Wanasundara, (1996). These rational changes were in higher amounts in the MWH-treated samples. When the samples were compared, the most noteworthy changes were seen in the Control, RCO, $\mathrm{SCO}+\mathrm{AP}$ and $\mathrm{SCO}+\mathrm{ROS}$ samples, respectively, in descending order. It was observed that the PUFA content decreased while SFA increased at elevated temperatures. The PUFA content in the samples was significantly reduced after both $\mathrm{CVH}$ and $\mathrm{MWH}$ treatments. However, the MWH treatment resulted in a higher level of reduction in PUFA content when compared to CVH-treated samples. Caponio et al., (2003) noted that unsaturated fractions were significantly decreased by conventional electric oven and microwave heating in virgin olive oil, peanut and sunflower oils. Hassanein et al., (2003) reported a decrease in oleic and linoleic acid contents in some vegetable oils during microwave heating. Tan et al., (2001) indicated that the ratio of unsaturated fatty acids (UFA), such as linoleic acid, decreased during microwave heating while the sum of SFA increased in corn and soybean oils. The ratios between linoleic and some SFA are used as indicators of oil deterioration caused by oxidation (Tan et al., 2001). The total UFA content in $\mathrm{CVH}$ and $\mathrm{MWH}$ samples showed 9.5 and $12.9 \%$ reductions in the Control, while they were 2.9 and $7.7 \%$ in RCO, 3.6 and $6.1 \%$ in SCO+ROS and finally 4 and $4.8 \%$ in SCO+AP, respectively. The highest level of reduction in PUFA was observed in the Control followed by RCO, $\mathrm{SCO}+\mathrm{ROS}$ and $\mathrm{SCO}+\mathrm{AP}$. Therefore, it was concluded that AP was more effective in protecting PUFA compared to ROS and natural TOC.

\subsection{Peroxide value}

The hydroperoxide content, as a primary oxidation product, is usually shown by the PV. The PV of $\mathrm{CVH}$ and MWH samples are shown in Table 2. In both heating treatments, the PV of the samples significantly increased $(\mathrm{p}<0.05)$. The MWH samples showed higher PVs than their CVH counterparts $(p<0.05)$. As expected, the highest level of PV was reached in the Control at VII and VI time points for both $\mathrm{CVH}$ and MWH treatments (24.02 and $27.96 \mathrm{meq} \mathrm{O}_{2} / \mathrm{kg}$, respectively). In the CVH samples, there were no significant differences among the samples of RCO, $\mathrm{SCO}+\mathrm{ROS}$ and $\mathrm{SCO}+\mathrm{AP}$ at time point III; while these samples were significantly different from the Control in terms of PV $(p<0.05)$. On the other hand, in the MWH samples, there were no significant differences at the same time interval. In general, the PV of the samples increased up to a certain level in both heat treatments and later on decreased after a peak value. In both the $\mathrm{CVH}$ and MWH treatments, the Control, RCO, SCO+ROS and $\mathrm{SCO}+\mathrm{AP}$ reached their highest PV levels at VII and VI, VIII and VIII, IX and IX, and IX and VIII time points, respectively. After these time points, PV levels started to decrease and instead, HEX started to increase (Figure 1). Except for SCO+ROS samples, the correlation between the changes in PV and HEX was strong. As extensively reported by other researchers, hydroperoxides are converted into secondary oxidation products by oxidation as they are not stable (Javidipour et al., 2017; Tan et al., 2001). MWH-treated Control and SCO+AP samples reached peak values for PV earlier when compared 
TABLE 1. Changes in fatty acid composition (\%) during conventional and microwave heating

\begin{tabular}{|c|c|c|c|c|c|c|c|}
\hline \multirow[b]{2}{*}{ Sample } & \multirow{2}{*}{$\begin{array}{l}\text { Fatty } \\
\text { acids } \\
(\%)\end{array}$} & \multicolumn{3}{|c|}{ Conventional } & \multicolumn{3}{|c|}{ Microwave } \\
\hline & & I & IV & XI & I & IV & XI \\
\hline \multirow{10}{*}{$\begin{array}{l}\text { SCO } \\
\text { (Control) }\end{array}$} & $\mathrm{C} 16$ & $10.63 \pm 0.93^{\mathrm{aA} \alpha}$ & $10.09 \pm 1.40^{\mathrm{aA} \alpha}$ & $12.82 \pm 1.39^{\mathrm{bA \alpha}}$ & $10.18 \pm 0.52^{\mathrm{aA} \alpha}$ & $10.86 \pm 1.88^{\mathrm{aA} \alpha}$ & $11.72 \pm 1.6^{\mathrm{aA} \alpha}$ \\
\hline & $\mathrm{C} 18$ & $2.34 \pm 0.20^{\mathrm{aA} \alpha}$ & $3.31 \pm 0.23^{\mathrm{bA} \beta}$ & $3.73 \pm 0.18^{\mathrm{bA \alpha}}$ & $2.47 \pm 0.37^{\mathrm{aA} \alpha}$ & $3.28 \pm 0.38^{\mathrm{aA} \alpha}$ & $4.13 \pm 0.37^{\mathrm{bA} \beta}$ \\
\hline & $\mathrm{C} 18: 1$ & $31.43 \pm 1.80^{\mathrm{aA} \alpha}$ & $30.89 \pm 1.39^{\mathrm{aA} \alpha}$ & $29.77 \pm 0.74^{\mathrm{aA} \alpha}$ & $31.27 \pm 2.49^{\mathrm{aA} \alpha}$ & $30.61 \pm 2.16^{\mathrm{aA} \alpha}$ & $29.89 \pm 2.47^{\mathrm{aA \alpha}}$ \\
\hline & C18:2 & $53.61 \pm 2.66^{\mathrm{bA \alpha} \alpha}$ & $52.79 \pm 2.62^{\mathrm{bA} \alpha}$ & $47.21 \pm 1.39^{\mathrm{aB} \alpha}$ & $53.76 \pm 1.99^{\mathrm{bA \alpha} \alpha}$ & $50.59 \pm 2.59^{\mathrm{bA \alpha}}$ & $44.15 \pm 2.91^{\mathrm{aA} \alpha}$ \\
\hline & $\mathrm{C} 18: 3$ & $0.25 \pm 0.01^{\mathrm{aA} \alpha}$ & $0.21 \pm 0.03^{\mathrm{aA} \alpha}$ & $0.19 \pm 0.08^{\mathrm{aA} \alpha}$ & $0.28 \pm 0.07^{\mathrm{aA} \alpha}$ & $0.22 \pm 0.03^{\mathrm{aA} \alpha}$ & $0.14 \pm 0.06^{\mathrm{aA} \alpha}$ \\
\hline & Other & $1.74 \pm 0.25^{\mathrm{aA \alpha}}$ & $2.65 \pm 0.28^{\mathrm{aA} \alpha}$ & $6.28 \pm 0.75^{\mathrm{bA} \gamma}$ & $2.04 \pm 0.71^{\mathrm{aA} \alpha \beta}$ & $4.44 \pm 1.95^{\mathrm{abA} \alpha}$ & $9.91 \pm 0.31^{\mathrm{bB} \beta}$ \\
\hline & ¿SFA & $14.71 \pm 0.68^{\mathrm{aA} \alpha}$ & $16.05 \pm 1.09^{\mathrm{aA} \alpha}$ & $22.83 \pm 0.77^{\mathrm{bA} \beta}$ & $14.79 \pm 0.62^{\mathrm{aA \alpha} \alpha}$ & $18.58 \pm 1.07^{\mathrm{bA \alpha}}$ & $25.76 \pm 0.54^{\mathrm{cB} \beta}$ \\
\hline & ¿MUFA & $31.43 \pm 1.80^{\mathrm{aA} \alpha}$ & $30.89 \pm 1.39^{\mathrm{aA} \alpha}$ & $29.77 \pm 0.74^{\mathrm{aA} \alpha}$ & $31.27 \pm 2.49^{\mathrm{aA} \alpha}$ & $30.61 \pm 2.16^{\mathrm{aA} \alpha}$ & $29.89 \pm 2.47^{\mathrm{aA} \alpha}$ \\
\hline & ¿PUFA & $53.86 \pm 1.30^{\mathrm{bA \alpha} \alpha}$ & $53.00 \pm 1.78^{\mathrm{abA} \alpha}$ & $47.40 \pm 1.02^{\mathrm{aB} \alpha}$ & $53.84 \pm 0.52^{\mathrm{bA} \alpha}$ & $50.81 \pm 0.58^{\mathrm{bA} \alpha}$ & $44.29 \pm 2.32^{\mathrm{aA} \alpha}$ \\
\hline & $\Sigma$ UFA & $85.29 \pm 3.10^{\mathrm{bA \alpha}}$ & $83.89 \pm 3.17^{\mathrm{abB} \alpha}$ & $77.17 \pm 1.75^{\mathrm{aB} \alpha}$ & $85.11 \pm 1.97^{\mathrm{bA} \alpha}$ & $81.42 \pm 1.58^{\mathrm{abA} \alpha}$ & $74.18 \pm 4.79^{\mathrm{aA} \alpha}$ \\
\hline \multirow[t]{10}{*}{ RCO } & $\mathrm{C} 16$ & $10.87 \pm 1.33^{\mathrm{aA} \alpha}$ & $9.93 \pm 1.61^{\mathrm{aA} \alpha}$ & $13.80 \pm 1.82^{\mathrm{bB} \alpha}$ & $10.20 \pm 2.31^{\mathrm{aA} \alpha}$ & $11.42 \pm 1.44^{\mathrm{aA} \alpha}$ & $10.10 \pm 0.45^{\mathrm{aA} \alpha}$ \\
\hline & $\mathrm{C} 18$ & $2.30 \pm 0.21^{\mathrm{aA} \alpha}$ & $2.42 \pm 0.33^{\mathrm{aA} \alpha \beta}$ & $2.83 \pm 0.18^{\mathrm{aA} \alpha}$ & $2.27 \pm 0.2^{\mathrm{aA} \alpha}$ & $2.30 \pm 0.23^{\mathrm{aA} \alpha}$ & $3.21 \pm 0.42^{\mathrm{aA} \alpha \beta}$ \\
\hline & $\mathrm{C} 18: 1$ & $31.13 \pm 0.65^{\mathrm{aA} \alpha}$ & $30.12 \pm 2.47^{\mathrm{aA \alpha} \alpha}$ & $31.89 \pm 1.68^{\mathrm{aA} \alpha}$ & $29.10 \pm 2.94^{\mathrm{aA} \alpha}$ & $30.57 \pm 2.69^{\mathrm{aA} \alpha}$ & $30.22 \pm 2.09^{\mathrm{aA} \alpha}$ \\
\hline & $\mathrm{C} 18: 2$ & $54.20 \pm 2.43^{\mathrm{bA \alpha}}$ & $54.07 \pm 2.23^{\mathrm{bA} \alpha}$ & $49.01 \pm 3.18^{\mathrm{aB} \alpha}$ & $54.03 \pm 2.32^{\mathrm{bA} \alpha}$ & $51.60 \pm 2.14^{\mathrm{abA} \alpha}$ & $46.46 \pm 2.33^{\mathrm{aA} \alpha}$ \\
\hline & $\mathrm{C} 18: 3$ & $0.30 \pm 0.06^{\mathrm{aA \alpha}}$ & $0.31 \pm 0.04^{\mathrm{aA} \alpha}$ & $2.21 \pm 0.20^{\mathrm{bB} \beta}$ & $0.29 \pm 0.06^{\mathrm{aA} \alpha}$ & $0.32 \pm 0.04^{\mathrm{aA} \alpha}$ & $0.27 \pm 0.03^{\mathrm{aA \alpha}}$ \\
\hline & Other & $1.20 \pm 0.23^{\mathrm{aA} \alpha}$ & $3.15 \pm 0.45^{\mathrm{bA} \alpha}$ & $0.21 \pm 0.06^{\mathrm{aA} \alpha}$ & $4.11 \pm 0.65^{\mathrm{aB} \beta}$ & $3.79 \pm 0.17^{\mathrm{aA} \alpha}$ & $9.74 \pm 1.24^{\mathrm{bB} \alpha \beta}$ \\
\hline & ¿SFA & $14.37 \pm 0.40^{\mathrm{aA} \alpha}$ & $15.50 \pm 0.49^{\mathrm{abA} \alpha}$ & $16.84 \pm 0.27^{\mathrm{bA} \alpha}$ & $16.58 \pm 0.76^{\mathrm{aA} \alpha \beta}$ & $17.51 \pm 0.89^{\mathrm{aA} \alpha}$ & $23.05 \pm 1.43^{\mathrm{bB} \alpha \beta}$ \\
\hline & ¿MUFA & $31.13 \pm 0.65^{\mathrm{aA} \alpha}$ & $30.12 \pm 2.47^{\mathrm{aA} \alpha}$ & $31.89 \pm 1.68^{\mathrm{aA} \alpha}$ & $29.10 \pm 2.94^{\mathrm{aA} \alpha}$ & $30.57 \pm 2.69^{\mathrm{aA} \alpha}$ & $30.22 \pm 2.09^{\mathrm{aA} \alpha}$ \\
\hline & ¿PUFA & $54.50 \pm 2.49^{\mathrm{bA \alpha}}$ & $54.38 \pm 2.27^{\mathrm{bA} \alpha}$ & $51.22 \pm 3.38^{\mathrm{aB} \alpha}$ & $54.32 \pm 2.38^{\mathrm{bA} \alpha}$ & $51.92 \pm 2.18^{\mathrm{bA} \alpha}$ & $46.73 \pm 2.36^{\mathrm{aA} \alpha}$ \\
\hline & $\Sigma$ UFA & $85.63 \pm 2.51^{\mathrm{bA \alpha} \alpha}$ & $84.50 \pm 2.67^{\mathrm{abA \alpha} \alpha}$ & $83.11 \pm 3.02^{\mathrm{a} B \alpha}$ & $83.42 \pm 2.78^{\mathrm{bA \alpha} \alpha}$ & $82.49 \pm 2.59^{\mathrm{bA} \alpha}$ & $76.95 \pm 2.64^{\mathrm{aA} \alpha}$ \\
\hline \multirow[t]{10}{*}{ SCO+ROS } & $\mathrm{C} 16$ & $10.64 \pm 0.83^{\mathrm{aA} \alpha}$ & $8.68 \pm 0.62^{\mathrm{aA \alpha}}$ & $10.57 \pm 2.11^{\mathrm{aA} \alpha}$ & $10.76 \pm 1.54^{\mathrm{aA} \alpha}$ & $9.90 \pm 1.84^{\mathrm{aA} \alpha}$ & $10.30 \pm 1.50^{\mathrm{aA} \alpha}$ \\
\hline & $\mathrm{C} 18$ & $2.36 \pm 0.21^{\mathrm{aA \alpha}}$ & $2.01 \pm 0.04^{\mathrm{aA} \alpha}$ & $2.95 \pm 0.59^{\mathrm{aA} \alpha}$ & $2.41 \pm 0.31^{\mathrm{aA} \alpha}$ & $2.44 \pm 0.04^{\mathrm{aB} \alpha}$ & $2.52 \pm 0.21^{\mathrm{aA} \alpha}$ \\
\hline & $\mathrm{C} 18: 1$ & $31.47 \pm 2.28^{\mathrm{aA} \alpha}$ & $29.26 \pm 2.25^{\mathrm{aA} \alpha}$ & $30.78 \pm 2.32^{\mathrm{aA} \alpha}$ & $31.69 \pm 2.23^{\mathrm{aA} \alpha}$ & $31.42 \pm 2.39^{\mathrm{aA} \alpha}$ & $30.81 \pm 1.94^{\mathrm{aA} \alpha}$ \\
\hline & $\mathrm{C} 18: 2$ & $54.00 \pm 2.45^{\mathrm{bA} \alpha}$ & $53.87 \pm 3.05^{\mathrm{bA \alpha}}$ & $51.43 \pm 2.36^{\mathrm{aB} \alpha}$ & $53.70 \pm 2.19^{\mathrm{bA \alpha}}$ & $52.62 \pm 2.43^{\mathrm{bA \alpha}}$ & $49.42 \pm 3.83^{\mathrm{aA} \alpha}$ \\
\hline & $\mathrm{C} 18: 3$ & $0.31 \pm 0.04^{\mathrm{bA \alpha} \alpha}$ & $0.13 \pm 0.04^{\mathrm{aA} \alpha}$ & $0.13 \pm 0.03^{\mathrm{aA} \alpha}$ & $0.29 \pm 0.06^{\mathrm{aA \alpha}}$ & $0.19 \pm 0.13^{\mathrm{aA \alpha}}$ & $0.18 \pm 0.07^{\mathrm{aA} \alpha}$ \\
\hline & Other & $1.22 \pm 0.24^{\mathrm{aA} \alpha}$ & $5.99 \pm 0.48^{\mathrm{cB} \beta}$ & $4.08 \pm 0.31^{\mathrm{bA} \beta}$ & $1.15 \pm 0.27^{\mathrm{aA} \alpha}$ & $3.37 \pm 0.52^{\mathrm{bA \alpha}}$ & $6.77 \pm 0.55^{\mathrm{cB} \alpha}$ \\
\hline & ¿SFA & $14.22 \pm 0.49^{\mathrm{aA} \alpha}$ & $16.68 \pm 0.58^{\mathrm{bA \alpha} \alpha}$ & $17.60 \pm 1.20^{\mathrm{bA} \alpha}$ & $14.32 \pm 0.52^{\mathrm{aA} \alpha}$ & $15.71 \pm 0.33^{\mathrm{aA} \alpha}$ & $19.59 \pm 0.69^{\mathrm{bB} \alpha}$ \\
\hline & ¿MUFA & $31.47 \pm 2.28^{\mathrm{aA} \alpha}$ & $29.26 \pm 2.25^{\mathrm{aA \alpha} \alpha}$ & $30.78 \pm 2.32^{\mathrm{aA} \alpha}$ & $31.69 \pm 2.23^{\mathrm{aA} \alpha}$ & $31.42 \pm 2.39^{\mathrm{aA} \alpha}$ & $30.81 \pm 1.94^{\mathrm{aA} \alpha}$ \\
\hline & ¿PUFA & $54.31 \pm 2.49^{\mathrm{bA \alpha} \alpha}$ & $54.00 \pm 3.09^{\mathrm{bA \alpha}}$ & $51.56 \pm 2.39^{\mathrm{aA} \alpha}$ & $53.99 \pm 2.25^{\mathrm{bA \alpha}}$ & $52.81 \pm 2.56^{\mathrm{bA \alpha} \alpha}$ & $49.60 \pm 3.90^{\mathrm{aA} \alpha}$ \\
\hline & $\Sigma$ UFA & $85.78 \pm 1.33^{\mathrm{bA \alpha} \alpha}$ & $83.26 \pm 0.78^{\mathrm{abA \alpha}}$ & $82.34 \pm 3.83^{\mathrm{aA} \alpha}$ & $85.68 \pm 1.98^{\mathrm{bA \alpha} \alpha}$ & $84.23 \pm 0.71^{\mathrm{bA \alpha}}$ & $80.41 \pm 2.73^{\mathrm{aA} \alpha}$ \\
\hline \multirow[t]{10}{*}{$\mathrm{SCO}+\mathrm{AP}$} & $\mathrm{C} 16$ & $10.95 \pm 1.70^{\mathrm{aA} \alpha}$ & $10.80 \pm 1.33^{\mathrm{aA} \alpha}$ & $11.28 \pm 1.78^{\mathrm{aA \alpha} \alpha}$ & $10.83 \pm 0.59^{\mathrm{aA} \alpha}$ & $9.90 \pm 1.60^{\mathrm{aA} \alpha}$ & $10.24 \pm 1.73^{\mathrm{aA} \alpha}$ \\
\hline & $\mathrm{C} 18$ & $2.53 \pm 0.16^{\mathrm{aA} \alpha}$ & $2.83 \pm 0.2^{\mathrm{aA} \alpha \beta}$ & $3.13 \pm 0.51^{\mathrm{aA} \alpha}$ & $2.49 \pm 0.23^{\mathrm{aA} \alpha}$ & $2.70 \pm 0.48^{\mathrm{aA} \alpha}$ & $3.26 \pm 0.25^{\mathrm{aA} \alpha \beta}$ \\
\hline & C18:1 & $30.98 \pm 1.56^{\mathrm{aA} \alpha}$ & $29.71 \pm 1.15^{\mathrm{aA} \alpha}$ & $30.52 \pm 3.73^{\mathrm{aA \alpha} \alpha}$ & $31.07 \pm 3.31^{\mathrm{aA} \alpha}$ & $31.28 \pm 1.85^{\mathrm{aA} \alpha}$ & $30.15 \pm 3.2^{\mathrm{aA} \alpha}$ \\
\hline & $\mathrm{C} 18: 2$ & $53.50 \pm 2.59^{\mathrm{bA} \alpha}$ & $53.40 \pm 2.43^{\mathrm{bA \alpha} \alpha}$ & $50.70 \pm 2.79^{\mathrm{aA} \alpha}$ & $51.90 \pm 3.75^{\mathrm{bA \alpha}}$ & $50.99 \pm 1.65^{\mathrm{bA \alpha}}$ & $48.82 \pm 1.43^{\mathrm{aA} \alpha}$ \\
\hline & $\mathrm{C} 18: 3$ & $0.28 \pm 0.04^{\mathrm{aA} \alpha}$ & $0.23 \pm 0.07^{\mathrm{aA} \alpha}$ & $0.13 \pm 0.04^{\mathrm{aA} \alpha}$ & $0.30 \pm 0.03^{\mathrm{aA} \alpha}$ & $0.27 \pm 0.08^{\mathrm{aA} \alpha}$ & $0.22 \pm 0.04^{\mathrm{aA} \alpha}$ \\
\hline & Other & $1.76 \pm 0.33^{\mathrm{aA} \alpha}$ & $3.03 \pm 0.33^{\mathrm{abA \alpha} \alpha}$ & $4.18 \pm 0.64^{\mathrm{bA} \beta \gamma}$ & $3.41 \pm 0.35^{\mathrm{a} \beta}$ & $4.86 \pm 0.23^{\mathrm{aB} \alpha}$ & $7.31 \pm 0.51^{\mathrm{bB} \alpha \beta}$ \\
\hline & ¿SFA & $15.24 \pm 1.23^{\mathrm{aA} \alpha}$ & $16.66 \pm 1.53^{\mathrm{abA} \alpha}$ & $18.59 \pm 2.29^{\mathrm{bA} \alpha}$ & $16.73 \pm 0.82^{\mathrm{aA} \beta}$ & $17.46 \pm 2.08^{\mathrm{abA \alpha} \alpha}$ & $20.81 \pm 1.98^{\mathrm{bA} \alpha}$ \\
\hline & ¿MUFA & $30.98 \pm 1.56^{\mathrm{aA} \alpha}$ & $29.71 \pm 1.15^{\mathrm{aA} \alpha}$ & $30.52 \pm 3.73^{\mathrm{aA} \alpha}$ & $31.07 \pm 3.31^{\mathrm{aA} \alpha}$ & $31.28 \pm 1.85^{\mathrm{aA} \alpha}$ & $30.15 \pm 3.20^{\mathrm{aA} \alpha}$ \\
\hline & ¿PUFA & $53.78 \pm 2.63^{\mathrm{bA} \alpha}$ & $53.63 \pm 2.50^{\mathrm{bA \alpha} \alpha}$ & $50.83 \pm 2.83^{\mathrm{aA \alpha} \alpha}$ & $52.20 \pm 3.78^{\mathrm{bA \alpha}}$ & $51.26 \pm 1.73^{\mathrm{abA \alpha}}$ & $49.04 \pm 1.47^{\mathrm{aA} \alpha}$ \\
\hline & ¿UFA & $84.76 \pm 2.70^{\mathrm{aA} \alpha}$ & $83.34 \pm 2.38^{\mathrm{aA} \alpha}$ & $81.35 \pm 3.05^{\mathrm{aA \alpha} \alpha}$ & $83.27 \pm 3.26^{\mathrm{aA} \alpha}$ & $82.54 \pm 1.98^{\mathrm{aA} \alpha}$ & $79.19 \pm 2.34^{\mathrm{aA} \alpha}$ \\
\hline
\end{tabular}

Each value in the table represents the mean \pm standard deviation of triplicate $(n=3)$ analyses. SFA: Saturated fatty acids, MUFA: Monounsaturated fatty acids, PUFA: Polyunsaturated fatty acids, UFA: Unsaturated fatty acids FA: Fatty acid, Control (SCO): Antioxidant free (stripped) corn oil, RCO: Corn oil with its natural TOC content ( $890 \mathrm{ppm})$; SCO+ROS: Stripped corn oil with 800 ppm rosemary extract; SCO+AP: Stripped corn oil with $200 \mathrm{ppm}$ ascorbyl palmitate. Different lower case Latin letters within the same row show significant differences among different heating periods within each heating method. Different upper case Latin letters within the same row show significant differences among the same heating periods of 2 different heating methods. Different Greek letters within the same column show significant differences in the same fatty acid of different samples. Differences were significant at the level of 0.05 as compared by the Tukey test. 
TABLE 2. Peroxide value $\left(\mathrm{meqO}_{2} / \mathrm{kg}\right)$ of samples during conventional and microwave heating

\begin{tabular}{|c|c|c|c|c|}
\hline Period/Temperature & SCO (Control) & RCO & SCO+ROS & $\mathrm{SCO}+\mathrm{AP}$ \\
\hline \multicolumn{5}{|l|}{ Conventional } \\
\hline I $\left(22^{\circ} \mathrm{C}\right)$ & $4.11 \pm 0.41^{\mathrm{aA}}$ & $4.99 \pm 0.32^{\mathrm{aA}}$ & $4.14 \pm 0.72^{\mathrm{aA}}$ & $4.23 \pm 0.68^{\mathrm{aA}}$ \\
\hline II $\left(93^{\circ} \mathrm{C}\right)$ & $7.33 \pm 0.59^{\mathrm{abB}}$ & $5.47 \pm 0.23^{\mathrm{abAB}}$ & $4.42 \pm 0.66^{\mathrm{abA}}$ & $4.62 \pm 0.42^{\mathrm{abA}}$ \\
\hline III $\left(148^{\circ} \mathrm{C}\right)$ & $9.37 \pm 0.75^{\text {bcB }}$ & $6.27 \pm 0.42^{\mathrm{abA}}$ & $5.33 \pm 0.59^{\mathrm{abA}}$ & $6.27 \pm 0.77^{\mathrm{abcA}}$ \\
\hline IV $\left(184^{\circ} \mathrm{C}\right)$ & $13.59 \pm 1.54^{\mathrm{deB}}$ & $8.44 \pm 0.55^{\mathrm{bcA}}$ & $6.51 \pm 0.68^{\mathrm{abcA}}$ & $8.01 \pm 0.93^{\mathrm{bcA}}$ \\
\hline $\mathrm{V}\left(206^{\circ} \mathrm{C}\right)$ & $16.57 \pm 0.95^{\mathrm{efC}}$ & $10.72 \pm 0.21^{\mathrm{cdeB}}$ & $7.15 \pm 0.46^{\mathrm{bcdA}}$ & $9.23 \pm 0.35^{\mathrm{cdAB}}$ \\
\hline VI $\left(219^{\circ} \mathrm{C}\right)$ & $21.71 \pm 2.02^{\mathrm{ghB}}$ & $12.49 \pm 1.65^{\mathrm{deA}}$ & $7.32 \pm 0.29^{\mathrm{bcdA}}$ & $11.87 \pm 0.16^{\mathrm{deA}}$ \\
\hline VII $\left(233^{\circ} \mathrm{C}\right)$ & $24.02 \pm 0.14^{\mathrm{hC}}$ & $17.06 \pm 0.80^{\mathbf{f B}}$ & $8.57 \pm 0.33^{\text {cdeA }}$ & $14.12 \pm 1.51^{\mathrm{efB}}$ \\
\hline VIII $\left(248^{\circ} \mathrm{C}\right)$ & $19.30 \pm 1.10^{\mathrm{fgB}}$ & $19.12 \pm 0.67^{\mathrm{fB}}$ & $9.87 \pm 1.34^{\mathrm{defA}}$ & $16.20 \pm 0.50^{\mathbf{f B}}$ \\
\hline IX $\left(262^{\circ} \mathrm{C}\right)$ & $12.93 \pm 0.70^{\mathrm{cdeAB}}$ & $17.39 \pm 1.28^{\mathrm{fBC}}$ & $12.03 \pm 0.78^{\mathrm{fA}}$ & $17.43 \pm 1.45^{\mathrm{fC}}$ \\
\hline $\mathrm{X}\left(271^{\circ} \mathrm{C}\right)$ & $10.92 \pm 0.88^{\text {bcdA }}$ & $13.60 \pm 0.73^{\mathrm{eA}}$ & $11.60 \pm 0.45^{\mathrm{fA}}$ & $14.27 \pm 1.42^{\mathrm{efA}}$ \\
\hline $\mathrm{XI}\left(284^{\circ} \mathrm{C}\right)$ & $8.05 \pm 0.46^{\mathbf{a b A}}$ & $9.98 \pm 0.44^{\mathrm{cdAB}}$ & $11.03 \pm 1.05^{\mathrm{efB}}$ & $9.88 \pm 0.39^{\mathrm{cdAB}}$ \\
\hline \multicolumn{5}{|l|}{ Microwave } \\
\hline I (initial) & $4.11 \pm 0.60^{\mathrm{aA}}$ & $4.29 \pm 0.27^{\mathrm{aA}}$ & $4.29 \pm 0.39^{\mathrm{aA}}$ & $4.31 \pm 0.38^{\mathrm{aA}}$ \\
\hline II (2 min) & $8.56 \pm 1.01^{\mathrm{abcB}}$ & $5.68 \pm 0.19^{\mathrm{aA}}$ & $5.18 \pm 0.84^{\mathrm{abA}}$ & $5.08 \pm 0.35^{\mathrm{abA}}$ \\
\hline III (4 min) & $11.61 \pm 0.74^{\mathrm{cdA}}$ & $8.81 \pm 0.70^{\mathrm{abcA}}$ & $6.89 \pm 0.36^{\mathrm{abcA}}$ & $7.52 \pm 3.61^{\mathrm{abcA}}$ \\
\hline IV (6 min) & $17.15 \pm 1.72^{\mathrm{eA}}$ & $10.99 \pm 0.06^{\mathrm{bcdB}}$ & $7.74 \pm 0.86^{\mathrm{bcdB}}$ & $9.78 \pm 0.39^{\mathrm{bcdB}}$ \\
\hline $\mathrm{V}(8 \mathrm{~min})$ & $22.76 \pm 1.81^{\mathrm{fC}}$ & $14.65 \pm 1.27^{\mathrm{deB}}$ & $8.17 \pm 0.64^{\mathrm{cdA}}$ & $11.70 \pm 0.52^{\text {cdeAB }}$ \\
\hline VI (10 min) & $27.96 \pm 2.32^{\mathrm{gC}}$ & $18.66 \pm 0.97^{\mathrm{efB}}$ & $9.96 \pm 0.40^{\mathrm{deA}}$ & $15.45 \pm 0.29^{\mathrm{efB}}$ \\
\hline VII (12 min) & $26.38 \pm 0.79^{\mathrm{fgC}}$ & $22.91 \pm 0.93^{\mathrm{fgBC}}$ & $11.19 \pm 0.63^{\text {efA }}$ & $18.39 \pm 1.80^{\mathrm{fgB}}$ \\
\hline VIII (16 min) & $15.97 \pm 0.52^{\mathrm{deAB}}$ & $24.09 \pm 2.82^{\mathrm{gC}}$ & $13.30 \pm 1.12^{\mathrm{fgA}}$ & $21.08 \pm 0.38^{\mathrm{gBC}}$ \\
\hline IX (20 min) & $11.08 \pm 0.46^{\mathrm{bcA}}$ & $19.14 \pm 1.16^{\mathrm{efC}}$ & $14.99 \pm 0.63^{\mathrm{gB}}$ & $18.66 \pm 0.64^{\mathrm{fgC}}$ \\
\hline $\mathrm{X}(24 \min )$ & $7.83 \pm 0.97^{\mathrm{abcA}}$ & $12.26 \pm 1.57^{\mathrm{cdAB}}$ & $15.58 \pm 1.21^{\mathrm{gB}}$ & $13.05 \pm 0.13^{\mathrm{deB}}$ \\
\hline XI (30 min) & $6.37 \pm 0.67^{\mathrm{abA}}$ & $6.81 \pm 0.57^{\mathrm{abA}}$ & $12.80 \pm 0.47^{\mathrm{efgB}}$ & $10.02 \pm 1.04^{\mathrm{bcdB}}$ \\
\hline
\end{tabular}

Each value in the table represents the mean \pm standard deviation of triplicate $(n=3)$ analyses. Control (SCO): Antioxidant free (stripped) corn oil, RCO: Corn oil with its natural TOC content ( 890 ppm); SCO+ROS: Stripped corn oil with 800 ppm rosemary extract; SCO+AP: Stripped corn oil with 200 ppm ascorbyl palmitate. Different lower case letters within the same column show significant differences among different heating periods of the same sample within each heating method. Different upper case letters within the same row show significant differences among the samples within each heating method. Differences were significant at the level of 0.05 as compared by the Tukey test.

to their CVH-treated counterparts. This shows that the MWH-treated samples were deteriorated earlier. Based on the observations of PV, CVH samples can be considered more stable. When resistance to hydroperoxide formation was evaluated, the samples can be ordered as $\mathrm{SCO}+\mathrm{ROS}>\mathrm{SCO}+\mathrm{AP}>\mathrm{RCO}>$ Control in terms of stability. High temperature processes like microwave and deep frying are previously reported to be responsible for the gradual reduction in tocopherol content (Vieira and Regitano-D'arce, 1998). In fact, some studies showed that microwave heating for 8 to $10 \mathrm{~min}$ reduces levels of tocopherols in linseed, olive and palm oils, and the longer heating time, the higher the peroxide values (Vieira and Regitano-D'arce, 1998). Javidipour et al., (2017) noted that 9 min of microwave heating resulted in $41.24,37.0,17.18$, and $14.54 \%$ loss in total TOC content in olive, hazelnut, sunflower and soy bean oils, respectively. In this study, ROS samples showed the lowest level of PV increase while it was the highest in the Control for both heating treatments. Previous studies reported that ROS was more effective in the prevention of oxidation with higher antioxidant activity in comparison with TOC isomers (Chen et al., 2014). Chu and Hsu (1999) investigated various compounds including AP, ROS and TOC for their antioxidant effects on peanut oil. As reported in this study, ROS revealed the greatest effect, followed by AP and TOC. In previous studies, longer MWH treatment was reported to be responsible for a significant reduction in TOC content as well as dramatic increments in oxidation products (Javidipour et al., 2017; Vieira and Regitano-D'arce, 1998).

\subsection{Hexanal content}

HEX is a secondary metabolite formed during the oxidation of linoleic acid, which is the major fatty acid in corn oil. HEX is commonly used as an 

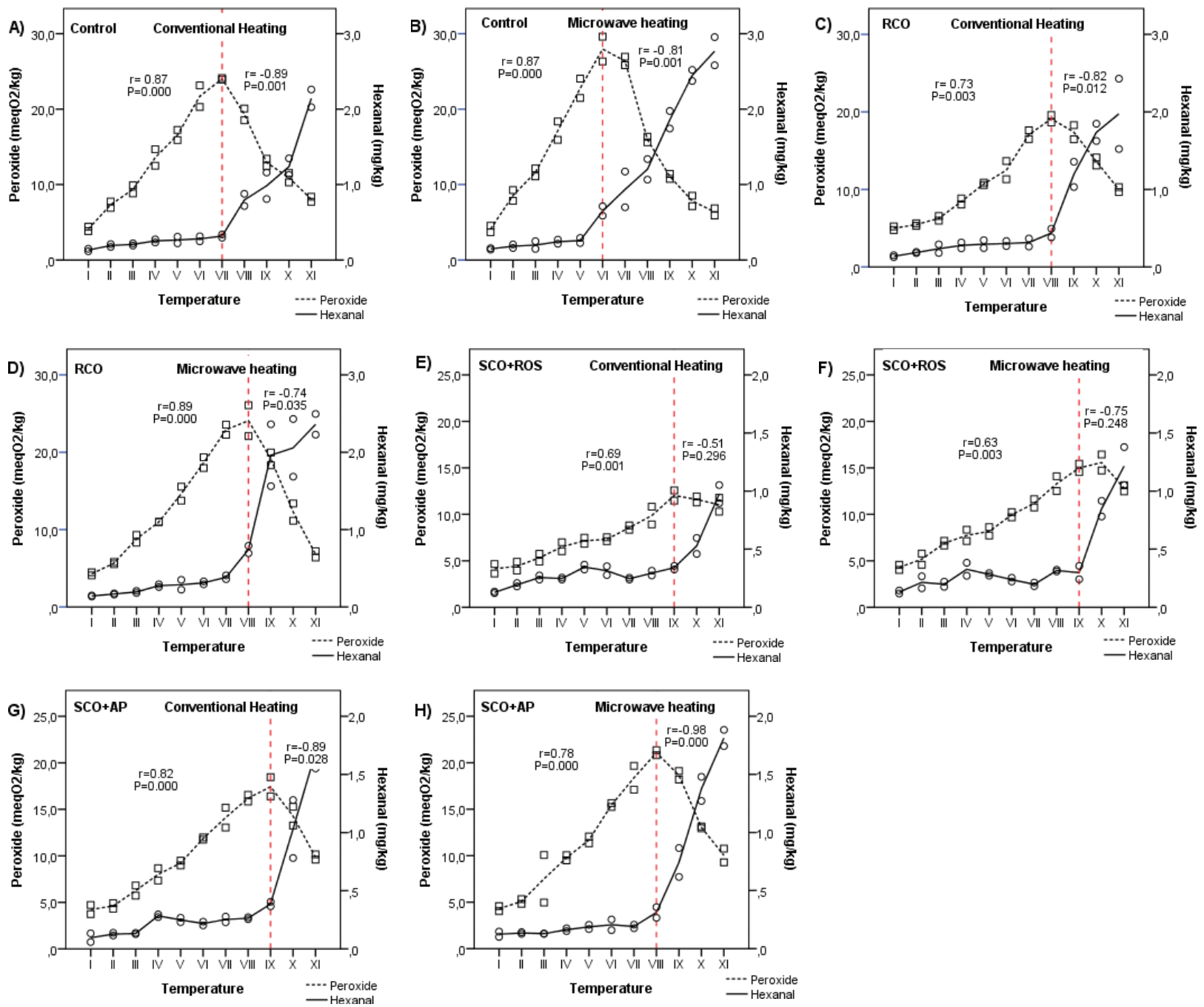

FIGURE 1. Changes in peroxide value $(\mathrm{meqO} / 2 / \mathrm{kg})$ and hexanal $(\mathrm{mg} / \mathrm{kg})$ content of corn oil samples heated by conventional and microwave ovens in the presence of different antioxidants.

Control: Antioxidant free (stripped) corn oil, RCO: Corn oil with its natural TOC content (890 ppm); SCO+ROS: Stripped corn oil with 800 ppm rosemary extract; SCO+AP: Stripped corn oil with 200 ppm ascorbyl palmitate.

indicator of oxidative deterioration (Frankel, 2010; Shahidi, 1998). The HEX contents of the samples in both $\mathrm{CVH}$ and $\mathrm{MWH}$ are given in Table 3 for different periods of heating. Considering the HEX values, differences between the Control and RCO was not significant up to time point VII of MWH, but later on significant differences were observed $(p<0.05)$. The HEX values for SCO+AP did not show any significant changed up to time point IX for both heating treatments but then, the difference was significant (Table 3). SCO+ROS was the one with the lowest level of HEX increment. Significant increments in HEX values were observed in MWH samples after time point $\mathrm{V}$ for the Control, time point VIII for both RCO and $\mathrm{SCO}+\mathrm{AP}$, and time point IX for SCO+ROS $(\mathrm{p}<0.05)$ (Figure 1). Generally speaking, the HEX values for the samples were Control $>\mathrm{RCO}>\mathrm{SCO}+\mathrm{AP}>\mathrm{SCO}+\mathrm{ROS}$, in the descending order. When heating methods were compared, MWH was seen to lead to higher level of HEX values. In both heating methods, it was observed that HEX values started to increase when PV level started to decrease (Figure 1). This is most probably because of the conversion of hydroperoxides into secondary oxidation products. According to Javidipour et al., (2017), the simultaneous evaluation of PV and HEX levels showed that a considerable amount of peroxides was converted to HEX during microwave heating. Kiralan and Kiralan (2015) noted that the HEX content in hazelnut oil increased from an initial value of 5.58 to 7.08 area units after $8 \mathrm{~min}$ exposure to microwave heating. Javidipour et al., (2017) indicated that HEX was the only oxidation product that continuously increased 
Effects of microwave and conventional heating on the oxidative stability of corn oil enriched with different antioxidants $\bullet 9$

TABLE 3. Hexanal content $(\mathrm{mg} / \mathrm{kg})$ of samples during conventional and microwave heating

\begin{tabular}{|c|c|c|c|c|}
\hline Period/Temperature & SCO (Control) & RCO & SCO+ROS & $\mathrm{SCO}+\mathrm{AP}$ \\
\hline \multicolumn{5}{|l|}{ Conventional } \\
\hline $\mathrm{I}\left(22^{\circ} \mathrm{C}\right)$ & $0.132 \pm 0.023^{\mathrm{aA}}$ & $0.139 \pm 0.018^{\mathrm{aA}}$ & $0.128 \pm 0.010^{\mathrm{aA}}$ & $0.096 \pm 0.052^{\mathrm{aA}}$ \\
\hline II $\left(93^{\circ} \mathrm{C}\right)$ & $0.192 \pm 0.027^{\mathrm{aA}}$ & $0.186 \pm 0.011^{\mathrm{aA}}$ & $0.194 \pm 0.020^{\mathrm{abA}}$ & $0.127 \pm 0.017^{\mathrm{aA}}$ \\
\hline III $\left(148^{\circ} \mathrm{C}\right)$ & $0.207 \pm 0.021^{\mathrm{aA}}$ & $0.236 \pm 0.078^{\mathrm{aA}}$ & $0.256 \pm 0.024^{\mathrm{abA}}$ & $0.132 \pm 0.007^{\mathrm{aA}}$ \\
\hline IV $\left(184^{\circ} \mathrm{C}\right)$ & $0.253 \pm 0.030^{\mathrm{aA}}$ & $0.278 \pm 0.054^{\mathrm{aA}}$ & $0.247 \pm 0.011^{\mathrm{abA}}$ & $0.285 \pm 0.016^{\mathrm{aA}}$ \\
\hline $\mathrm{V}\left(206^{\circ} \mathrm{C}\right)$ & $0.265 \pm 0.061^{\mathrm{aA}}$ & $0.294 \pm 0.072^{\mathrm{aA}}$ & $0.346 \pm 0.030^{\mathrm{bcA}}$ & $0.249 \pm 0.027^{\mathrm{aA}}$ \\
\hline $\mathrm{VI}\left(219^{\circ} \mathrm{C}\right)$ & $0.281 \pm 0.048^{\mathrm{aA}}$ & $0.302 \pm 0.045^{\mathrm{aA}}$ & $0.315 \pm 0.054^{\mathrm{abA}}$ & $0.218 \pm 0.023^{\mathrm{aA}}$ \\
\hline VII $\left(233^{\circ} \mathrm{C}\right)$ & $0.317 \pm 0.030^{\mathrm{aA}}$ & $0.315 \pm 0.072^{\mathrm{aA}}$ & $0.246 \pm 0.011^{\mathrm{abA}}$ & $0.253 \pm 0.034^{\mathrm{aA}}$ \\
\hline VIII $\left(248^{\circ} \mathrm{C}\right)$ & $0.796 \pm 0.115^{\mathrm{bB}}$ & $0.438 \pm 0.079^{\mathrm{abA}}$ & $0.294 \pm 0.030^{\mathrm{abA}}$ & $0.264 \pm 0.011^{\mathrm{aA}}$ \\
\hline IX $\left(262^{\circ} \mathrm{C}\right)$ & $0.984 \pm 0.247^{\mathrm{bcAB}}$ & $1.194 \pm 0.231^{\mathrm{bcB}}$ & $0.341 \pm 0.021^{\mathrm{bcA}}$ & $0.386 \pm 0.027^{\mathrm{aA}}$ \\
\hline $\mathrm{X}\left(271^{\circ} \mathrm{C}\right)$ & $1.238 \pm 0.156^{\mathrm{cAB}}$ & $1.736 \pm 0.157^{\mathrm{cB}}$ & $0.528 \pm 0.098^{\mathrm{cA}}$ & $1.031 \pm 0.352^{\mathrm{bAB}}$ \\
\hline $\mathrm{XI}\left(284^{\circ} \mathrm{C}\right)$ & $2.142 \pm 0.165^{\mathrm{dA}}$ & $1.975 \pm 0.642^{\mathrm{cA}}$ & $0.974 \pm 0.110^{\mathrm{dA}}$ & $1.688 \pm 0.192^{\mathrm{cA}}$ \\
\hline \multicolumn{5}{|l|}{ Microwave } \\
\hline I (initial) & $0.147 \pm 0.014^{\mathrm{aA}}$ & $0.142 \pm 0.008^{\mathrm{aA}}$ & $0.131 \pm 0.018^{\mathrm{aA}}$ & $0.124 \pm 0.033^{\mathrm{aA}}$ \\
\hline II (2 min) & $0.183 \pm 0.033^{\mathrm{aA}}$ & $0.168 \pm 0.010^{\mathrm{aA}}$ & $0.215 \pm 0.072^{\mathrm{aA}}$ & $0.135 \pm 0.010^{\mathrm{aA}}$ \\
\hline III (4 min) & $0.198 \pm 0.072^{\mathrm{aA}}$ & $0.194 \pm 0.020^{\mathrm{aA}}$ & $0.198 \pm 0.031^{\mathrm{aA}}$ & $0.129 \pm 0.001^{\mathrm{aA}}$ \\
\hline IV (6 min) & $0.242 \pm 0.038^{\mathrm{aA}}$ & $0.276 \pm 0.024^{\mathrm{aA}}$ & $0.327 \pm 0.079^{\mathrm{aA}}$ & $0.163 \pm 0.017^{\mathrm{aA}}$ \\
\hline $\mathrm{V}(8 \mathrm{~min})$ & $0.258 \pm 0.047^{\mathrm{aA}}$ & $0.287 \pm 0.091^{\mathrm{aA}}$ & $0.283 \pm 0.016^{\mathrm{aA}}$ & $0.187 \pm 0.025^{\mathrm{aA}}$ \\
\hline VI (10 min) & $0.649 \pm 0.088^{\mathrm{abB}}$ & $0.312 \pm 0.027^{\mathrm{aA}}$ & $0.238 \pm 0.023^{\mathrm{aA}}$ & $0.205 \pm 0.065^{\mathrm{aA}}$ \\
\hline VII (12 min) & $0.935 \pm 0.335^{\mathrm{bB}}$ & $0.384 \pm 0.035^{\mathrm{aAB}}$ & $0.197 \pm 0.021^{\mathrm{aA}}$ & $0.191 \pm 0.021^{\mathrm{aA}}$ \\
\hline VIII (16 min) & $1.202 \pm 0.194^{\mathrm{bB}}$ & $0.743 \pm 0.068^{\mathrm{aA}}$ & $0.316 \pm 0.010^{\mathrm{aA}}$ & $0.311 \pm 0.065^{\mathrm{aA}}$ \\
\hline IX (20 min) & $1.859 \pm 0.164^{\mathrm{cB}}$ & $1.962 \pm 0.566^{\mathrm{bB}}$ & $0.298 \pm 0.081^{\mathrm{aA}}$ & $0.742 \pm 0.175^{\mathrm{bAB}}$ \\
\hline$X(24 \min )$ & $2.447 \pm 0.103^{\mathrm{cdB}}$ & $2.058 \pm 0.528^{\mathrm{bB}}$ & $0.849 \pm 0.096^{\mathrm{bA}}$ & $1.375 \pm 0.147^{\mathrm{cAB}}$ \\
\hline XI (30 min) & $2.768 \pm 0.264^{\mathrm{dC}}$ & $2.361 \pm 0.190^{\mathrm{bBC}}$ & $1.215 \pm 0.232^{\mathrm{cA}}$ & $1.813 \pm 0.099^{\mathrm{dAB}}$ \\
\hline
\end{tabular}

Each value in the table represents the mean \pm standard deviation of triplicate $(n=3)$ analyses. Control (SCO): Antioxidant free (stripped) corn oil, RCO: Corn oil with its natural TOC content (890 ppm); SCO+ROS: Stripped corn oil with 800 ppm rosemary extract; SCO+AP: Stripped corn oil with 200 ppm ascorbyl palmitate. Different lower case letters within the same column show significant differences among different heating periods of the same sample within each heating method. Different upper case letters within the same row show significant differences among the samples within each heating method. Differences were significant at the level of 0.05 as compared by the Tukey test.

during microwave heating in hazelnut, olive, soybean and sunflower oils.

\subsection{Kinetic analysis}

The kinetic analysis was only performed on the MWH samples, as the heating times were evident. For the evaluation of oxidation rate, PV and HEX levels were used for the calculation of kinetic parameters. As mentioned earlier, a strong relationship was observed between peroxide degradation and HEX formation during microwave heating. HEX values started to increase simultaneously while PV started to decrease after 12,16, 24 and 16 minutes in the Control, RCO, SCO+ROS and SCO+AP, respectively. The corresponding kinetic data are summarized in Table 4. A strong negative correlation was observed between PV and HEX values after relevant heating periods (Figure 1B, 1D, 1F, 1H). The highest
TABLE 4. Reaction rate constants $\left(\mathrm{k}_{1}\right.$ and $\left.\mathrm{k}_{2}\right)$ and reaction orders $(\alpha$ and $\beta)$ for formation of peroxides $\left(\mathrm{meqO}_{2} / \mathrm{kg}\right)$ and hexanal $(\mathrm{mg} / \mathrm{kg})$ during microwave heating

\begin{tabular}{lcccc}
\hline Sample & $\mathbf{k}_{\mathbf{1}}$ & $\alpha$ & $\mathbf{k}_{\mathbf{2}}$ & $\beta$ \\
\hline SCO (Control) & 1.128 & 0.5 & 0.125 & 1.046 \\
RCO & 0.659 & 1.8 & 0.561 & 1.898 \\
SCO+ROS & 0.707 & 1.4 & 0.608 & 1.451 \\
SCO+AP & 0.540 & 1.6 & 0.384 & 1.751 \\
\hline
\end{tabular}

Control (SCO): Antioxidant free (stripped) corn oil, RCO: Corn oil with its natural TOC content ( 890 ppm); SCO+ROS: Stripped corn oil with 800 ppm rosemary extract; SCO+AP: Stripped corn oil with $200 \mathrm{ppm}$ ascorbyl palmitate.

rate constant was in the Control for $\mathrm{PV}$, which was followed by SCO+ROS, RCO and SCO+AP, as seen in Table 4. This was most probably due to differences in the level of activities of antioxidants that significantly reduced peroxide formation. In general, 
rate constants of primary oxidation products were higher compared to those of secondary oxidation products for all the samples. Changes in the concentration of primary and secondary oxidation products (Tables 2 and 3, respectively) and reaction rate constants regarding these changes (Table 4) showed that $\mathrm{SCO}+\mathrm{ROS}$ had higher oxidative stability as followed by $\mathrm{SCO}+\mathrm{AP}, \mathrm{RCO}$ and the Control. In terms of secondary oxidation products, $\mathrm{SCO}+\mathrm{ROS}$ showed the highest rate constant while it was the lowest in the Control. The rate of hydroperoxide decomposition increases with temperature while hydroperoxide concentration reaches its maximum and then decreases at advanced stages of oxidation (Crapiste et al., 1999). Reducing hydroperoxide concentration seems to decrease the rate of oxidation as the secondary oxidation products were formed by the decomposition of hydroperoxides. Hydroperoxides, which are transitory intermediates in oxidized oils, can break down into 2 free radicals ( $\mathrm{RO} \bullet$ and $\mathrm{OH} \bullet$ ) or 2 free radicals ( $\mathrm{ROO}^{\bullet}, \mathrm{RO} \bullet$ ) and water. This branching steps leads to proliferation of free radicals, which may participate in the propagation step (Hamilton et al., 1997). Therefore, the lower initial hydroperoxide concentration could directly affect the reaction rate of secondary oxidation products. In fact, the concentration of initial hydroperoxides directly affected the reaction rate of secondary oxidation products excluding the Control. The results showed that the reaction order of peroxide $(\alpha)$ and hexanal $(\beta)$ formation was first ordered (excluding the Control). The order of a reaction is important as it indicates the functional relationship between concentration and rate. How any amount of a compound speeds up or retards a reaction is determined by the order of reaction. As for PV, it has a reaction rate of zero, which means that it has a rate which is not dependent on the concentration of the reactant. On the other hand, the first order reaction, as for HEX formation, indicates that this reaction depends on the concentration of a single reacting compound (Göksunger, 2011). Basturk et al., (2007) studied reaction rates and orders on the formation of primary (peroxide value) and secondary oxidation products (anisidine value) for soy bean oil during storage at 45,60 , and $75^{\circ} \mathrm{C}$. They noted that the reaction rates increased at elevated temperatures for both primary and secondary oxidation products as also observed in the reaction order of primary oxidation products. In fact, the simultaneous generation of both primary and secondary oxidation products may be occurring during oxidation.

\subsection{Conjugated Dienes (K232) and Trienes (K270)}

Lipids have no innate chromophores for optical detection while the formation of radicals in unsaturated fatty acids consisting of 2 or more double bonds causes a shift in double bond position, converting non-conjugated fatty acids to conjugated counterparts (Schaich, 2016). Therefore, conjugated dienes are relatively stable chemical markers of oxidation in polyunsaturated fatty acids. A trend in changes in K232 values is given in Table 5 for both $\mathrm{CVH}$ and $\mathrm{MWH}$ samples. There was a significant difference among heating treatments in terms of K232 values ( $\mathrm{p}<0.05)$. However, MWH samples reached higher values of K232 in comparison with CVH samples. Generally speaking, K232 values increased up to time points IX and $X$, and later on started to decrease (Table 5). Vieira and Regitano-D'arce, (1998) reported that absorption at $232 \mathrm{~nm}$ of canola, corn and soybean oils increased gradually after 12 min of microwave exposure, and absorption at $270 \mathrm{~nm}$ significantly increased after 4 min of heating. The highest K232 values were seen in the Control $>\mathrm{RCO}>\mathrm{SCO}+\mathrm{AP}>\mathrm{SCO}+\mathrm{ROS}$, in descending order. The findings from this study are in good agreement with the data previously reported by Albi et al., (1997). There was no significant difference between heating methods although the K270 values for each sample significantly changed during heating (data not shown). Lukesova et al., (2009) reported that the $\mathrm{PV}, \mathrm{K} 232$ and $\mathrm{K} 270$ in rapeseed, corn, soybean and sunflower oils increased due to microwave heating. They also noted that K232 were formed at higher levels compared to K270. Vieira and Regitano-D'arce (1998) and Lukesova et al., (2009) noted that K232 was a good index for measuring oil deterioration after microwave heating.

\section{CONCLUSIONS}

The level of increments in PV, K232 and HEX were higher in $\mathrm{MWH}$, which indicates a lower oxidative stability in microwave treatment compared to conventional heating. An overview of the results led to the conclusion that the resistance of the samples to oxidative deterioration was in the descending order of $\mathrm{SCO}+\mathrm{ROS}>\mathrm{SCO}+\mathrm{AP}>\mathrm{RCO}>\mathrm{SCO}$. This indicated that ROS and AP were both very effective in the deferral of oxidative deterioration. In parallel with PV increment, K232 values were especially high in MWH samples due to the shifting of double bonds by conjugation and isomerization. The formation of $\mathrm{K} 232$ in the samples was in the order of Control $>\mathrm{RCO}>\mathrm{SCO}+\mathrm{AP}>\mathrm{SCO}+\mathrm{ROS}$. Similarly, the HEX increment was higher in the MWH samples. It was observed that PV decreased while HEX increased toward the end of both heating treatments. In addition, the ratio of PUFA decreased and SFA increased while no significant change was observed in MUFA during heating. A kinetic analysis of the data showed that the reaction of peroxide and hexanal formation was first-ordered. The reaction rate was in the order of Control $>\mathrm{SCO}+\mathrm{ROS}>$ $\mathrm{RCO}>\mathrm{SCO}+\mathrm{AP}$ for $\mathrm{PV}$; while it was $\mathrm{SCO}+\mathrm{ROS}>$ $\mathrm{RCO}>\mathrm{SCO}+\mathrm{AP}>$ Control for HEX. 
Effects of microwave and conventional heating on the oxidative stability of corn oil enriched with different antioxidants $\bullet 11$

TABLE 5. Changes in conjugated dienes $\left(\mathrm{E}_{\mathrm{cm}}^{1 \%}\right.$ at $\left.232 \mathrm{~cm}\right)$ during conventional and microwave heating

\begin{tabular}{|c|c|c|c|c|}
\hline Period/Temperature & SCO (Control) & RCO & SCO+ROS & $\mathrm{SCO}+\mathrm{AP}$ \\
\hline \multicolumn{5}{|l|}{ Conventional } \\
\hline I $\left(22^{\circ} \mathrm{C}\right)$ & $3.27 \pm 0.28^{\mathrm{aA}}$ & $2.54 \pm 0.26^{\mathrm{aA}}$ & $3.35 \pm 0.37^{\mathrm{abA}}$ & $2.73 \pm 0.47^{\mathrm{aA}}$ \\
\hline II $\left(93^{\circ} \mathrm{C}\right)$ & $3.29 \pm 0.29^{\mathrm{aA}}$ & $3.45 \pm 0.33^{\mathrm{abA}}$ & $3.45 \pm 0.41^{\mathrm{abA}}$ & $3.42 \pm 0.31^{\mathrm{abA}}$ \\
\hline III $\left(148^{\circ} \mathrm{C}\right)$ & $3.64 \pm 0.24^{\mathrm{aA}}$ & $4.36 \pm 0.24^{\mathrm{abA}}$ & $3.83 \pm 0.57^{\mathrm{abA}}$ & $3.61 \pm 0.18^{\mathrm{abA}}$ \\
\hline IV $\left(184^{\circ} \mathrm{C}\right)$ & $4.30 \pm 0.22^{\mathrm{aA}}$ & $4.74 \pm 0.31^{\mathrm{abA}}$ & $4.21 \pm 0.57^{\mathrm{abA}}$ & $3.88 \pm 0.61^{\mathrm{abcA}}$ \\
\hline $\mathrm{V}\left(206^{\circ} \mathrm{C}\right)$ & $7.06 \pm 0.31^{\mathrm{bC}}$ & $4.89 \pm 0.36^{\mathrm{abB}}$ & $3.23 \pm 0.38^{\mathrm{aA}}$ & $4.05 \pm 0.43^{\mathrm{abcAB}}$ \\
\hline VI $\left(219^{\circ} \mathrm{C}\right)$ & $8.39 \pm 0.37^{\mathbf{b c C}}$ & $5.60 \pm 0.38^{\mathrm{bB}}$ & $3.62 \pm 0.33^{\mathrm{abA}}$ & $4.78 \pm 0.66^{\text {bcdAB }}$ \\
\hline VII $\left(233^{\circ} \mathrm{C}\right)$ & $9.20 \pm 0.79^{\mathbf{b c B}}$ & $8.59 \pm 0.45^{\mathrm{cB}}$ & $3.52 \pm 0.37^{\mathrm{abA}}$ & $5.44 \pm 0.29^{\mathrm{cdA}}$ \\
\hline VIII $\left(248^{\circ} \mathrm{C}\right)$ & $8.95 \pm 0.42^{\mathrm{bcB}}$ & $8.44 \pm 0.53^{\mathrm{cB}}$ & $5.30 \pm 0.52^{\mathrm{bcA}}$ & $6.43 \pm 0.35^{\mathrm{deA}}$ \\
\hline IX $\left(262^{\circ} \mathrm{C}\right)$ & $9.35 \pm 0.67^{\mathbf{b c B}}$ & $9.30 \pm 0.52^{\mathrm{cB}}$ & $6.97 \pm 0.27^{\mathrm{cdA}}$ & $8.26 \pm 0.39^{\mathrm{fAB}}$ \\
\hline $\mathrm{X}\left(271^{\circ} \mathrm{C}\right)$ & $10.02 \pm 1.14^{\mathrm{cA}}$ & $8.51 \pm 0.35^{\mathbf{c A}}$ & $7.28 \pm 0.90^{\operatorname{cdA}}$ & $8.07 \pm 0.38^{\mathrm{efA}}$ \\
\hline XI $\quad\left(284^{\circ} \mathrm{C}\right)$ & $9.07 \pm 1.28^{\mathrm{bcA}}$ & $9.45 \pm 1.80^{\mathbf{c A}}$ & $7.36 \pm 0.68^{\mathrm{dA}}$ & $8.61 \pm 0.30^{\mathrm{fA}}$ \\
\hline \multicolumn{5}{|l|}{ Microwave } \\
\hline I (initial) & $2.76 \pm 0.21^{\mathrm{aA}}$ & $2.84 \pm 0.17^{\mathrm{aA}}$ & $3.18 \pm 0.49^{\mathrm{abA}}$ & $2.86 \pm 0.08^{\mathrm{aA}}$ \\
\hline II $(2 \mathrm{~min})$ & $3.27 \pm 0.17^{\mathrm{aA}}$ & $3.74 \pm 0.26^{\mathrm{abA}}$ & $3.10 \pm 0.16^{\mathrm{aA}}$ & $3.58 \pm 0.44^{\mathrm{abA}}$ \\
\hline III (4 min) & $5.42 \pm 0.42^{\mathrm{abC}}$ & $4.95 \pm 0.31^{\mathrm{abcBC}}$ & $3.18 \pm 0.51^{\mathrm{abA}}$ & $3.57 \pm 0.45^{\mathrm{abAB}}$ \\
\hline IV $(6 \mathrm{~min})$ & $7.91 \pm 1.17^{\mathrm{abcc}}$ & $5.98 \pm 0.34^{\mathrm{bcdB}}$ & $3.44 \pm 0.50^{\mathrm{abA}}$ & $4.63 \pm 0.45^{\mathrm{bcAB}}$ \\
\hline $\mathrm{V}(8 \mathrm{~min})$ & $10.31 \pm 1.17^{\mathrm{bcC}}$ & $7.11 \pm 0.33^{\text {cdeB }}$ & $4.15 \pm 0.29 \mathrm{a}^{\mathrm{bA}}$ & $5.86 \pm 0.48^{\text {cdeAB }}$ \\
\hline VI (10 min) & $12.14 \pm 1.38^{\mathrm{cB}}$ & $8.01 \pm 0.17^{\text {defA }}$ & $5.50 \pm 0.96^{\mathrm{bcA}}$ & $5.54 \pm 0.27^{\mathrm{cdA}}$ \\
\hline VII (12 min) & $12.71 \pm 2.66^{\mathrm{cA}}$ & $10.27 \pm 1.52^{\mathrm{fA}}$ & $6.65 \pm 0.52^{\mathrm{cdA}}$ & $6.90 \pm 0.39^{\mathrm{deA}}$ \\
\hline VIII (16 min) & $11.94 \pm 1.11^{\mathrm{cB}}$ & $9.53 \pm 1.21^{\mathrm{efAB}}$ & $7.73 \pm 0.59^{\text {cdeA }}$ & $7.48 \pm 0.54^{\mathrm{efA}}$ \\
\hline IX (20 min) & $11.01 \pm 2.56^{\mathrm{cA}}$ & $10.04 \pm 0.29^{\mathbf{f A}}$ & $8.93 \pm 0.29^{\mathrm{deA}}$ & $9.18 \pm 0.47^{\mathrm{fgA}}$ \\
\hline$X(24 \mathrm{~min})$ & $10.77 \pm 0.83^{\mathrm{bcA}}$ & $10.52 \pm 1.17^{\mathrm{fA}}$ & $8.67 \pm 0.59^{\mathrm{deA}}$ & $9.40 \pm 0.60^{\mathrm{gA}}$ \\
\hline XI $(30 \mathrm{~min})$ & $10.62 \pm 1.55^{\mathrm{bcA}}$ & $9.85 \pm 0.39^{\text {efA }}$ & $9.98 \pm 1.03^{\mathrm{eA}}$ & $9.08 \pm 0.48^{\mathrm{fgA}}$ \\
\hline
\end{tabular}

Each value in the table represents the mean \pm standard deviation of triplicate $(n=3)$ analyses. Control (SCO): Antioxidant free (stripped) corn oil, RCO: Corn oil with its natural TOC content $(890$ ppm); SCO+ROS: Stripped corn oil with 800 ppm rosemary extract; SCO+AP: Stripped corn oil with $200 \mathrm{ppm}$ ascorbyl palmitate. Different lower case letters within the same column show significant differences among different heating periods of the same sample within each heating method. Different upper case letters within the same row show significant differences among the samples within each heating method. Differences were significant at the level of 0.05 as compared by the Tukey test.

\section{ACKNOWLEDGMENTS}

The author would like to thank Prof. Dr. Issa Javidipour and Dr. Gökhan Boran of Van Yüzüncü Yll University for their critical reading of the manuscript and useful discussions.

\section{Conflict of interest}

The author has no conflict of interest to declare.

\section{REFERENCES}

Adhvaryu A, Erhan SZ, Liu ZS, Perez JM. 2000. Oxidation kinetic studies of oils derived from unmodified and genetically modified vegetables using pressurized differential scanning calorimetry and nuclear magnetic resonance spectroscopy. Thermochim. Acta 364, 87-97. https://doi. org/10.1016/S0040-6031(00)00626-2

Albi T, Lanzón A, Guinda A, Pérez-Camino MC, León M. 1997. Microwave and conventional heating effects on some physical and chemical parameters of edible fats. J. Agric. Food Chem. 45, 3000-3003. https://doi. org/10.1021/jf970168c

AOAC 1990. Official Methods of Analysis, Fifteenth edition. Association of Official Analysis Chemists, Washington, DC.

AOCS 1989. In Official methods and recommended practices of the American Oil Chemists' Society (4th ed.), AOCS Champaign, IL, USA.

AOCS 2003. Official Method Ce 8-89. Determination of tocopherols and tocotrienols in vegetable oils and fats by HPLC. In Official methods and recommended practices of the American Oil Chemists' Society (4th ed.), AOCS, Champaign, IL, USA.

Basturk A, Javidipour I, Boyaci IH. 2007. Oxidative stability of natural and chemically interesterified cottonseed, palm and soybean oils. J. Food Lipids 14,170-188. https://doi. org/10.1111/j.1745-4522.2007.00078.x

Baştürk A, Ceylan MM, Çavuş M, Boran G, Javidipour I. 2018. Effects of some herbal extracts on oxidative stability of corn oil under accelerated oxidation conditions in comparison with some commonly used antioxidants. $L W T$ Food Sci. Technol. 89, 358-64. https://doi.org/10.1016/j. lwt.2017.11.005

Benedini L, Schulz EP, Messina PV, Palma SD, Allemandi DA, Schulz PC. 2011. The ascorbyl palmitate-water system: 
Phase diagram and state of water. Colloid Surface A $\mathbf{3 7 5}$, 178-185. https://doi.org/10.1016/j.colsurfa.2010.11.083

Caponio F, Pasqualone A, Gomes T. 2003. Changes in the fatty acid composition of vegetable oils in model doughs submitted to conventional or microwave heating. Int. J. Food Sci. Tech. 38, 481-486. https://doi. org/10.1046/j.1365-2621.2003.00703.x

Chen XQ, Zhang Y, Zu YG, Yang L, Lu Q, Wang W. 2014. Antioxidant effects of rosemary extracts on sunflower oil compared with synthetic antioxidants. Int. J. Food Sci. Tech. 49, 385-91. https://doi.org/10.1111/ijfs.12311

Chu YH, Hsu HF. 1999. Effects of antioxidants on peanut oil stability. Food Chem. 66, 29-34. https://doi.org/10.1016/ S0308-8146(98)00082-X

Crapiste GH, Brevedan MI, Carelli AA. 1999. Oxidation of sunflower oil during storage. J. Am. Oil Chem. Soc. 76, 1437.

Frankel EN. 2010. Chemistry of extra virgin olive oil: adulteration, oxidative stability, and antioxidants. J. Agric. Food Chem. 58, 5991-6006. https://doi.org/10.1021/jf1007677

Göksunger Y. 2011.Reaction and Fermentation Kinetics in Food Engineering, Sidas Medya Ltd. Şti. Publisher: İzmir, Turkey.

Hamilton RJ, Kalu C, Prisk E, Padley F, Pierce H. 1997. Chemistry of free radicals in lipids. Food Chem. 60, 193-9. https://doi.org/10.1016/S0308-8146(96)00351-2

Hassanein MM, El-Shami SM, El-Mallah MH. 2003. Changes occurring in vegetable oils composition due to microwave heating. Grasas Aceites 54, 343-349. https://doi. org/10.3989/gya.2003.v54.i4.219

Javidipour I, Erinc H, Basturk A, Tekin A. 2017. Oxidative changes in hazelnut, olive, soybean, and sunflower oils during microwave heating. Int. J. Food Prop. 20, 1582-1592. http://doi.org/10.1080/10942912.2016.1214963

Javidipour I, Qian MC. 2008. Volatile component change in whey protein concentrate during storage investigated by headspace solid-phase microextraction gas chromatography. Dairy Sci. Technol. 88, 95-104. https://doi.org/10.1051/ dst: 2007010

Karel M. 1992. Kinetics of lipid oxidation, Phys Chem foods, New York: Marcel Dekker Inc., pp. 651-68.
Kiralan M, Kiralan SS. 2015. Changes in Volatile Compounds of Black Cumin Oil and Hazelnut Oil by Microwave Heating Process. J. Am. Oil Chem. Soc. 92, 1445-1450. https://doi. org/10.1007/s11746-015-2711-7

Lukesova D, Dostalova J, Mahmoud EEM, Svarovska M. 2009. Oxidation Changes of Vegetable Oils during Microwave Heating. Czech J. Food Sci. 27, S178-S181. https://doi. org/10.17221/929-CJFS

Labuza TP, Dugan Jr L. 1971. Kinetics of lipid oxidation in foods. Crit. Rev. Food Sci. 2,355-405. https://doi. org/10.1080/10408397109527127

Schaich K. 2016. 'Analysis of lipid and protein oxidation in fats, oils, and foods', Oxidative stability and shelf life of foods containing oils and fats, Elsevier, pp. 1-131.

Shahidi F. 1998. Indicators for evaluation of lipid oxidation and off-flavor development in food. Dev. Food Sci. 40, 55-68. https://doi.org/10.1016/S0167-4501(98)80032-0

Shahidi F, Wanasundara UN. 1996. Methods for evaluation of the oxidative stability of lipid-containing foods. Food Sci. Technol. Int. 2,73-81. https://doi.org/10.3136/ fsti9596t9798.2.73

Shahidi F, Zhong Y. 2005. Antioxidants: regulatory status. Bailey's industrial oil and fat products. 1, 491-512.

Tan CP, Man YBC, Jinap S, Yusoff MSA. 2001. Effects of microwave heating on changes in chemical and thermal properties of vegetable oils. J. Am. Oil Chem. Soc. 78,1227-1232. https://doi.org/10.1007/s11745-001-0418-5

Vieira TMFS, Regitano-D'arce MAB. 1998. Stability of oils heated by microwave: UV-spectrophotometric evaluation. Food Sci. Technol. 18, 433-437. http://doi.org/10.1590/ S0101-20611998000400015

Yoshida H, Kondo I, Kajimoto G. 1992a. Participation of Free Fatty-Acids in the Oxidation of Purified Soybean Oil during Microwave-Heating. J. Am. Oil Chem. Soc. 69,1136-40. https://doi.org/10.1007/Bf02541050

Yoshida H, Tatsumi M, Kajimoto G. 1992b. Influence of FattyAcids on the Tocopherol Stability in Vegetable-Oils during Microwave-Heating. J. Am. Oil Chem. Soc. 69, 119-25. https://doi.org/10.1007/Bf02540560 